\title{
Investigation of host-specificity of phytopathogenic fungi isolated from woody plants
}

\author{
Andrea Zabiák ${ }^{1}$ - Györk Milán Károlyi ${ }^{2}$ - Erzsébet Sándor ${ }^{1}$ \\ ${ }^{1}$ University of Debrecen, Faculty of Agricultural and Food Sciences and Environmental Management, Food Science Institute, Debrecen \\ ${ }^{2}$ University of Debrecen, Faculty of Agricultural and Food Sciences and Environmental Management, Plant Protection Institute, Debrecen \\ toth.andrea@agr.unideb.hu
}

\begin{abstract}
SUMMARY
Host-specificity is an important characteristic of fungal pathogens. Changing climate could create more appropriate environmental conditions for phytopathogens, thus formerly host-specify fungi could be able to colonize new hosts. Noxious plant pathogen fungi, which can infect several plant species are well-known worldwide. These genera may expand their range of hosts because of the appearance in new geographic areas due to climate change. This new exposure can result in serious problems in agriculture because of the lack of immunity. The susceptibility of apple tree was studied through testing pathogenicity in vitro with species isolated from walnut twigs and nuts, and identified by ITS sequences. Three of four tested species, Botryosphaeria dothidea, Diaporthe eres and Diplodia seriata colonized and necrotized the infected apple branches, while Juglanconis juglandina was not able to infect the twigs. Members of Botryosphaeriaceae were the most virulent, causing the largest lesions in the fastest way. This experiment draws attention to the threat of new host-pathogen connections, which can arise because of the favourable weather conditions and can spread between neighbouring cultures.
\end{abstract}

Keywords: apple, artificial inoculation, climate change, host-specificity, pathogenicity, woody tissues

\section{INTRODUCTION}

Fungi are present in all groups of plants as saprophytes or parasites, and some of them cannot grow without any host (Alexopoulos et al., 1996). They can spread on a global scale, which depends heavily on environmental factors. Their spore can move by rain, irrigation water, wind and insects, which allows to travel from one plant to another. However, diseases can spread slowly this way, new fungal diseases may appear in an another continent via infected seeds (Bandyopadhyay et al., 1998). Moreover, the role of human activities in fungal spore move is not negligible (Yarwood, 1983).

Host-specificity of phytopathogenic fungi and their ability to adapt a new plant is an interesting concept among plant pathologist. Host-specify fungi can grow only on one particular plant species, which phenomenon was studied also on a molecular biology basis and developed gene for gene thesis (Flor, 1971).

Climate change is threatening the whole world through extreme weather conditions, as increased temperature, monumental rainfall, droughts, hurricane or flooding (Costello et al., 2009). Because of the changed environment plants may contact with new pathogen, which never had been exposed before to, causing the lack of immunity. This means infections can spread into new hosts and new geographical areas (Hoberg and Brooks, 2015). Chestnut blight was introduced in similar way into the USA as well as sudden oak death (Emiko et al., 2007).

Plant diseases cause serious losses on a yearly basis, amounting to $10-16 \%$ of global food production (Strange and Scott, 2005; Chakraborty and Newton, 2011). Some changed environmental factors, such as higher humidity can provide favourable condition for fungi boosting disease risk and contribute to the development of diseases (Huber and Gllespie, 1992). Pathogens can overwinter more likely because of the increasing temperature, which predict plant protection problems after the dormant season (Coakley et al., 1999). Already for twenty years ago, researchers found, that some fungi cause more severe symptoms in warmer years (Brasier, 1996; Sutherland et al., 1997). The geographic ranges of pathogens may can alter due to climatic changes, as a result new host - pathogen connection can appear (Davis and Shaw, 2001), just like when plants were introduced in new continents in the past (Valent, 1990).

Members of the genus Botryosphaeria have been described in the United States as a pathogenic fungus responsible for apple decay, but were isolated from cankers of apple trees in Argentina, in Australia and in Brazil (Shay and Sitterly, 1954; Sutton, 1991). It has been observed, that the most harmful species of the genus colonize several hosts or are geographically widespread, because these species were often the most pathogenic in the case of artificial inoculation (de Wet et al., 2000; Pavlic et al., 2007; van Niekerk et al., 2004). Researchers have observed as well, that not all species cause infections in all areas, that have a broad host range. For example, Botryosphaeria dothidea causes serious infections in fruits and nuts in the United States, but is not at all or rarely found in these hosts in South Africa and other regions (Michailides, 1991; Pavlic et al., 2007; Slippers et al., 2004).

Diaporthe species caused cankerous lesions on apple tree in Japan as well as in South Africa, in Urugay, and on peach tree in Greece (Satoko et al., 1999; Smit et al., 1996; Thomas et al., 2009; Cloete et al., 2011; Sessa et al., 2017).

Diplodia genus are also able to colonize tissues of apple tree. Species were isolated from cankered parts in British Columbia and in Iran (Abdollahzadeh, 2015; Úrbez-Torres et al., 2016).

In 2017, a new genus named Juglanconis was described in Juglandaceae, separated from Melanconis genus, in addition new species were identified, 
however there may be further hidden groups (Voglmayr, 2017). Juglanconis juglandina is known for dieback of walnut (Juglans spp.) in Europe (Belisario, 1999). Regarding variable weather conditions in Hungary, the purpose of our study was to study host-specificity of some fungal genera and to reveal new possible host-pathogen relationships by (i) identify microbiome of woody tissues of apple tree and (ii) testing susceptibility of the plant against disjunctive pathogens, which can become potential threat of Hungarian agriculture due to changed environmental impacts.

\section{MATERIALS AND METHODS}

\section{Collection of fungal isolates}

In order to study the fungal microbiome of apple trees, samples were collected in Pallag, in the Horticulture Investigational Station of University of Debrecen. Seven tree were sampled which showed cankerous symptoms on trunks and branches. The bark tissues of collected plant pieces were removed, then they were disinfested in $10 \%$ chlorogen-sesquihydrate (Neomagnol)-Tween20 solution for one minute, and then the samples were washed in sterile distilled water twice. The woody tissues were placed on potatodextrose agar medium (Biolab) containing streptomycin-sulphate to minimize bacterial growth. Fungal colonies were transferred to fresh PDA media, following seven days of incubation at room temperature.

During the pathogenicity test, pathogen isolates were originated from walnut (Juglans regia) in similar way to the method mentioned above. The sampled orchard was near Jánkmajtis, where symptomatic twigs fruits were collected.

\section{Morphological and molecular biological identification}

Isolates were identified genus-level based on their cultural characteristics. Main morphological markers, colours and texture of colonies were studied on PDA.

Seven days old fungal colonies grown on PDA were used for DNA-extraction. Fungal mycelia were scraped with a sterile inoculation loop into tubes containing bashing beads. Genomic DNA was extracted with NucleoSpin Plant II (Macherey-Nagel) Kit. The ITS14 primers (IDT) of internal transcribed spacer (ITS) loci (White et al., 1990) were chosen to amplify variable sections of fungal gene with polymerase chain reaction. The reaction volume was $25 \mu \mathrm{L}: 12,5 \mu \mathrm{L}$ Green Master Mix (Thermo Fisher), $0,5 \mu \mathrm{L}$ of each primer (10 pmol/ $\mu \mathrm{L}), 10,5 \mu \mathrm{L}$ nuclease-free water and $1 \mu \mathrm{L}$ DNA $(10$ $\mu \mathrm{g} / \mu \mathrm{L})$. PCR products were purified with NucleoSpin Gel, PCR Clean Up Kit DNA (Macherey-Nagel) sequencing was performed in Microsynth $\mathrm{GmBh}$. Sequences were blast in National Center for Biotechnology Information (NCBI) resulting a list of the most similar strains.

\section{Artificial inoculation of apple twigs}

Pathogenicity tests were performed to investigate the susceptibility of plants, the manner and the rate of the spreading of fungal pathogens. To study whether canker-causing species isolated from other host plants could cause symptoms on apple tree, twigs were collected in Pallag. Twigs were washed in tap water and soaked in $70 \%$ ethanol for 3 minutes. After rinsing twice with sterile distilled water, the inoculation was performed. A V-shaped incision was formed in the centre of the sample with a scalpel, then a mycelium plug was placed in the wound, which was covered with laboratory film (Parafilm), as well as the cut ends of the twigs. The test was performed in triplicate. The inoculated branches were placed in a plastic box with Petri dish filled with sterile water to provide humidity. (Tang et al., 2011).

Measurements were carried out two, three, and four weeks later to determine the extent of pathogens in the samples. During the first two times, only the condition of the cortex was examined, and the internal tissues was examined at fourth week.

Pathogens were reisolate to determine, whether the inoculated fungi colonized the inner tissues of branches. The process was the same as described above in 'Collection of fungal isolate'.

\section{RESULTS AND DISCUSSIONS}

\section{Fungal community of apple twigs}

To crawl the present host-pathogen connections, fungal microbiome of apple tree was studied. In the cankerous apple branches, two Botrystis spp., four Diplodia spp., and Alternaria isolates were on the basis of colony morphology and conidial characters.

Isolates were collected for artificial inoculation of apple twigs, from plant parts of walnut, Botryosphaeria spp. and Diaporthe spp. from rotted walnuts, as well as Diplodia and Juglanconis genus from symptomatic walnut branches were cultured.

Colonies of Botrytis sp. were greyish and powdery, and the conidia were ovate. Members of Diplodia genus produced dark green pigments and ellipsoid conidia, as well as smaller aerial mycelia. Alternaria species created greenish colonies and this genus is wellknown for their conidia septate horizontally and vertically.

Cultures of Botryosphaeria were dark grey and rich in thick aerial mycelia, Diaporthe species were recognizable about their dirty white mycelia and black sclerotia. Juglanconis spp. generated bright yellow cultures on PDA.

For more accurate results, isolates were identified also with a molecular genetic method, which results confirmed our observations during genus-level identification. Based on ITS sequences, Alternaria alternata, Botrytis cinerea and Diplodia seriata were present in the apple branches. As far as walnut tree samples were concerned, Botryosphaeria dothidea and Diaporthe eres, Diplodia seriata and Juglanconis juglandina species were identified. These deposited isolates are summarized in Table 1. 
Species collecting from symptomatic apple branches and pathogens using during artificial inoculation

\begin{tabular}{|c|c|c|c|c|}
\hline Species & Host & Symptom & Geographical origin & $\begin{array}{c}\text { GenBank Accession } \\
\text { Number }\end{array}$ \\
\hline Alternaria alternata & Malus domestica & Cankered branch & Pallag, Hungary & MN706186 \\
\hline Diplodia sp. & Malus domestica & Cankered branch & Pallag, Hungary & MN706187 \\
\hline Diplodia sp. & Malus domestica & Cankered branch & Pallag, Hungary & MN706188 \\
\hline Diplodia seriata & Malus domestica & Cankered branch & Pallag, Hungary & MN706189 \\
\hline Botrytis cinerea & Malus domestica & Cankered branch & Pallag, Hungary & MN706190 \\
\hline Botrytis cinerea & Malus domestica & Cankered branch & Pallag, Hungary & MN706191 \\
\hline Botryosphaeria dothidea & Juglans regia & Rotted kernel & Jánkmajtis, Hungary & MN706192 \\
\hline Diaporthe eres & Juglans regia & Rotted kernel & Jánkmajtis, Hungary & MN706193 \\
\hline Diplodia seriata & Juglans regia & Symptomatic branch & Jánkmajtis, Hungary & MN706194 \\
\hline Juglanconis juglandina & Juglans regia & Symptomatic branch & Jánkmajtis, Hungary & MN706195 \\
\hline
\end{tabular}

\section{Pathogenicity test}

Botryosphaeria dothidea, Diaporthe eres, Diplodia seriata and Juglanconis juglandina from walnut were selected to setup pathogenicity test (Picture 1, Table 1). Two, three and four weeks after inoculation, the condition of the infected branches and the spread of the pathogens in tissues were examined.
Every tested pathogen caused symptoms on apple twig samples except Julganconis juglandina. (Picture $1 / \mathrm{G})$. In every case, the effect of artificial inoculation was manifested on the cortex (Picture 1/A) as well as in the vascular tissues (Picture 1/B, 1/C, 1/D, 1/E, 1/F). Control branches treated with empty PDA plug did not show lesions (Picture 1/H).

Picture 1: Effect of artificial inoculation. A: Pycnidia of Botryosphaeria dothidea on twig. B: Necrotic lesions caused by B. dothidea. C, D: Diaporthe eres induced symptoms in the phloem. E, F: Pathogenicity of Diplodia seriata. G: Symptomless branches treated with Juglanconis juglandina. H: Controls.
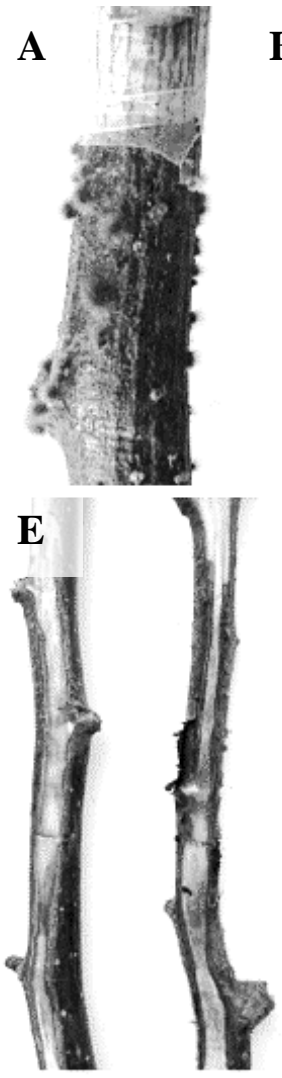
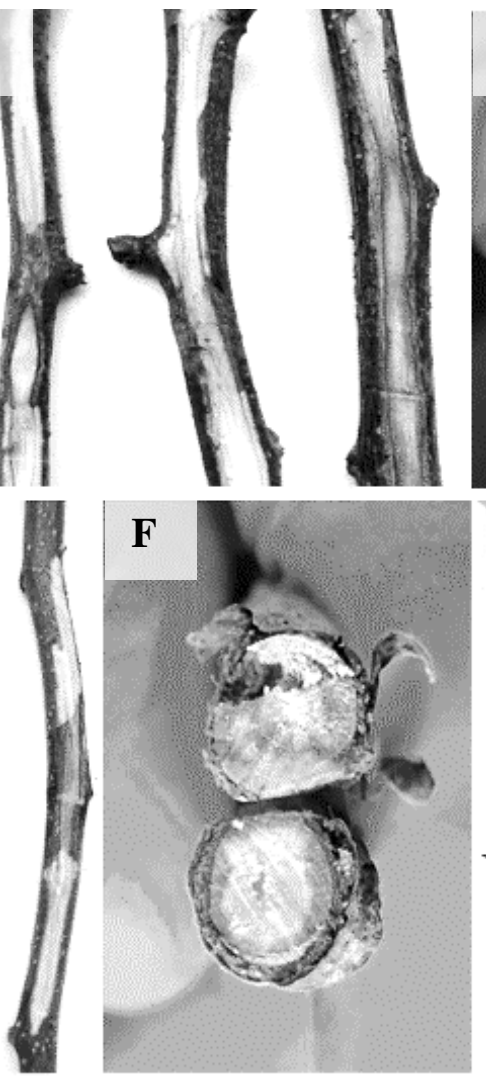
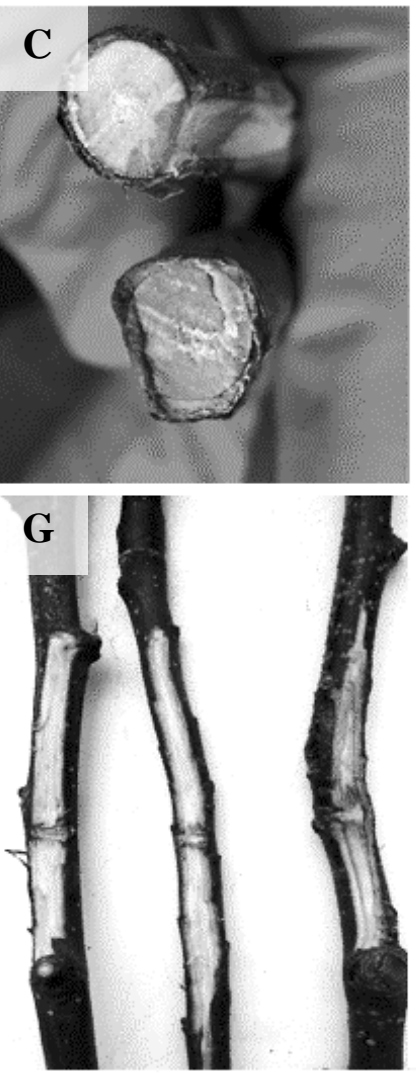
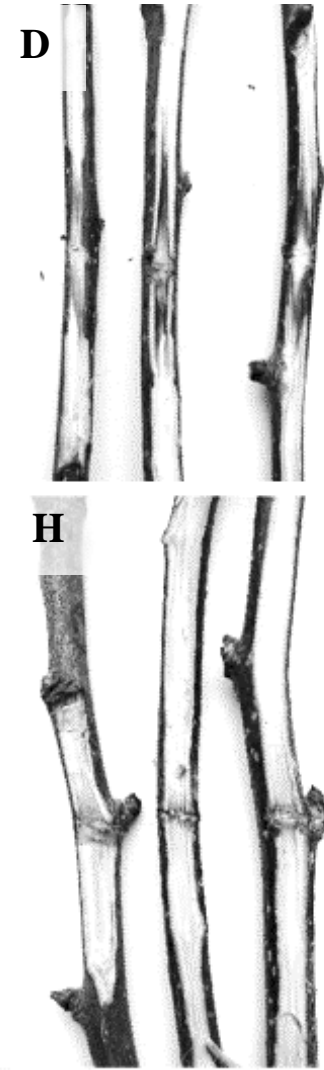
The spread of the lesions by weeks is illustrated in the Figure 1. Isolates belong to the Botryosphaeriaceae induced the most length lesions with the fastest spread. $B$. dothidea were more aggressive than $D$. seriata until the third week, however sizes of discolorations were almost the same at the fourth week. The negative effect of Diaporthe eres was much slower and the extent of the necrotic area were smaller also. Larger lesions were induced in the vascular tissues, when branches were treated with mycelia of $B$. dothidea, but mainly with $D$. eres. Although $D$. seriata produced serious necrotic symptoms in the phloem as well.

The reisolation of necrotic lesion induced fungi was successful. The fungal population of samples inoculated with Juglanconis juglandina was the same as the control, consequently this species was not able to colonize the apple twigs.

Canker-causing fungi, which had wide range of host could colonize and produce symptoms on woody tissues of apple. Despite belonging to Diaporthales order, J. juglandina, as its name show its pathogenicity may limit to member of Juglans spp.

$D$. seriata was present in symptomatic apple branches, which fact elucidated the high virulence of Botryopshaeriaceae during the pathogenicity test and supported the susceptibility of the host.

High standard deviation among triplicates require the repetition of the analysis with more replicates.

Figure 1: Summary results of the pathogenicity test. Error bar represent standard deviation

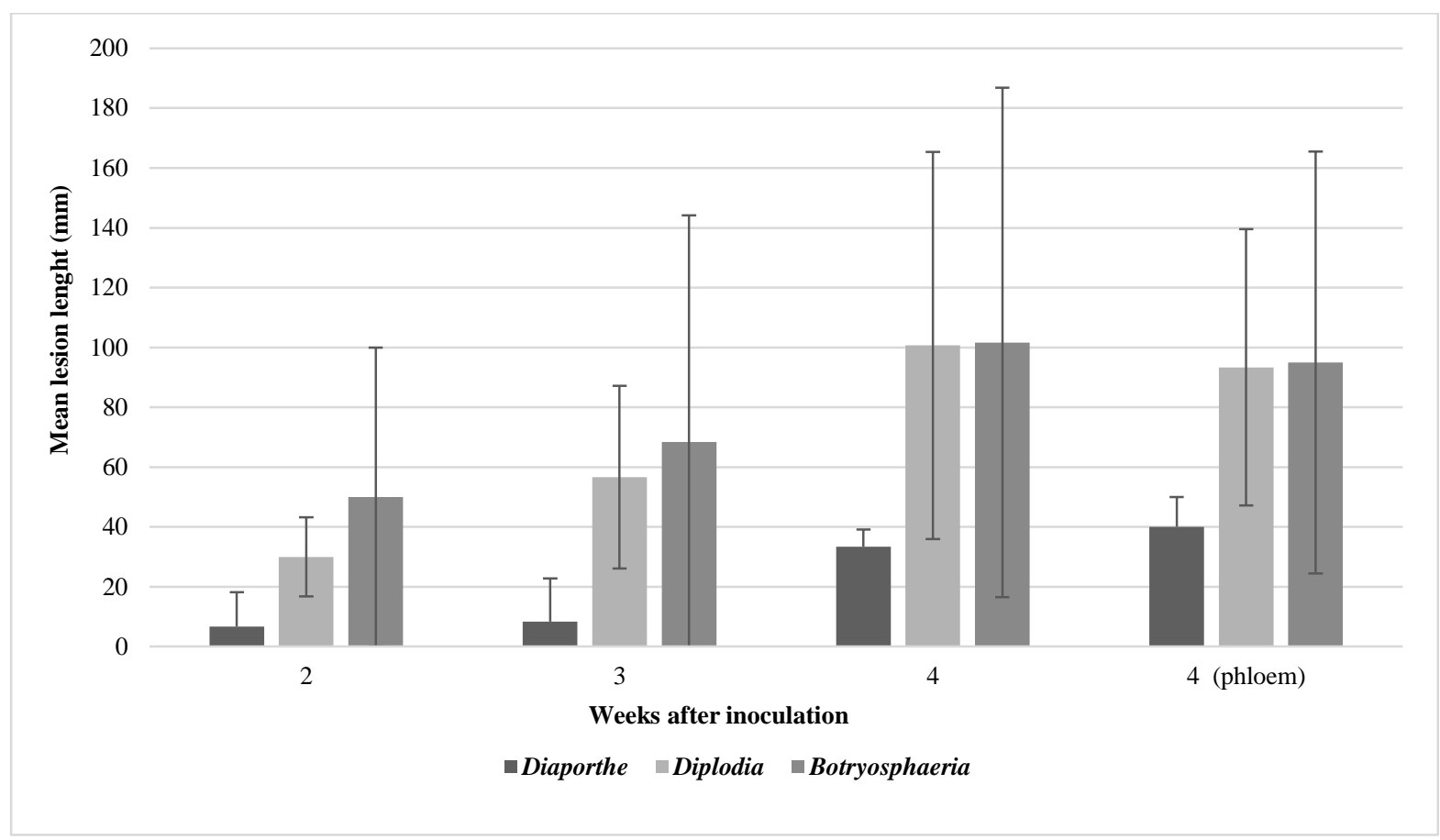

\section{CONCLUSIONS}

New host-pathogen relationships could appear because of the result of favourable environmental conditions for phytopathogenic fungi. Virulence of isolates were tested, which were present in apple twigs microbiome, and genera which were reported in apple woody tissues mainly in countries with warmer climate (Shay and Sitterly, 1954; Sutton, 1991; Smit et al., 1996; Thomas et al., 2009; Cloete et al., 2011; Abdollahzadeh, 2015; Sessa et al., 2017) and originated from rotted walnuts and symptomatic twigs.

After artificial inoculation, Botryosphaeria dothidea, Diaporthe eres and Diplodia seriata species not only colonized the woody tissues of apple, but also caused lesions. Juglanconis juglandina did not cause any symptoms in inoculated branches and did not colonize them, which is confirmed by unsuccessful reisolation. However, D. seriata was isolated from this orchard, B. dothidea and D. eres are considered a possible new host-pathogen interaction, which can result in devastating diseases later, being aware of their virulence on this tree.

Furthermore, the results of this paper support the importance of the monitoring of symptoms on neighbouring plant cultures due to possible crossinfection.

\section{ACKNOWLEDGEMENTS}

SUPPORTED BY THE ÚNKP-19-3 NEW NATIONAL EXCELLENCE PROGRAM OF THE MINISTRY FOR INNOVATION AND TECHNOLOGY.

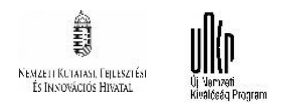




\section{REFERENCES}

Abdollahzadeh, J. (2015): Diplodia bulgarica, as a new pathogen and potential threat to the apple industry in Iran Phytopathologia Mediterranea. 54. 1: 128-132. https://doi.org/10.14601/Phytopathol_Mediterr-14686

Alexopoulos, C. J.-Mims, C. W.-Blackwell, M. (1996): Introductory Mycology. $4^{\text {th }}$ edition. Wiley. New York. 868.

Bandyopadhyay, R.-Frederickson, D. E.-McLaren, N. W.-Odvody, G. N.-Ryley, M. J. (1998): Ergot: A new disease threat to sorghum in the Americas and Australia. Plant Disease. 82. 4: 356-367. https://doi.org/10.1094/PDIS.1998.82.4.356

Belisario, A. (1999): Cultural characteristics and pathogenicity of Melanconium juglandinum. European Journal of Forest Pathology. 29. 5: 317-322. https://doi.org/10.1046/j.14390329.1999.00165.x

Brasier, C. M. (1996): Phytophthora cinnamomi and oak decline in southern Europe. Environmental constraints including climate change. Annals of Forest Science. 53. 2-3: 347-358. https://doi.org/10.1051/forest:19960217

Chakraborty, S.-Newton, A. C. (2011): Climate change, plant diseases and food security: an overview. Plant Pathology. 60. 1: 2-14. https://doi.org/10.1111/j.1365-3059.2010.02411.x

Cloete, M.-Fourie, P. H.-Damm, U.-Crous, P. W.-Mostert, L. (2011): Fungi associated with die-back symptoms of apple and pear trees, a possible inoculum source of grapevine trunk disease pathogens. Phytopathologia Mediterranea. 50. 176-190. https://doi.org/10.14601/Phytopathol_Mediterr-9004

Coakley, S. M.-Scherm, H.-Chakraborty, S. (1999): Climate change and plant disease management. Annual Review of Phytopathology. 37. 1: 399. https://doi.org/10.1146/annurev.phyto.37.1.399

Costello, A.-Abbas, M.-Allen A.-Ball, S.-Bell, S.-Bellamy, R.Friel, S.-Groce, N.-Johnson, A.-Kett, M. (2009): Managing the health effects of climate change. The Lancet Commisions. 373. 9676. 1693-1733. https://doi.org/10.1016/S0140 6736(09)60935-1

Davis, M. B.-Shaw, R. G. (2001): Range Shifts and Adaptive Responses to Quaternary Climate Change. Science. 292. 5517: 673-679. https://doi.org/10.1126/science.292.5517.673

de Wet, J.-Burguss, T.-Slippers, B.-Preisig, O.-Wingfield, B. D.Wingfield, M. J. (2003): Multiple gene genealogies and microsatellite markers reflect relationships between morphotypes of Sphaeropsis sapinea and distinguish a new species of Diplodia. Mycological Research. 107. 5: 557-566. https://doi.org/10.1017/S0953756203007706

Emiko, T.-Condeso, T.-Meentemeyer, R. K. (2007): Effects of landscape heterogeneity on the emerging forest disease sudden oak death. Journal of Ecology. 95. 2: 364-375. https://doi.org/10.1111/j.1365-2745.2006.01206.x

Flor, H. H. (1971): Current status of the gene-for-gene concept. Annual Review of Phytopathology. 9: 275-296. https://doi.org/10.1146/annurev.py.09.090171.001423

Hoeberg, E. P.-Brooks, D. R. (2015): Evolution in action: climate change, biodiversity dynamics and emerging infectious disease. Philosophical Transactions of the Royal Society B: Biological Sciences. 370. 1665. https://doi.org/10.1098/rstb.2013.0553

Huber, L.-Gllespie, T. J. (1992): Modeling Leaf Wetness in Relation to Plant Disease Epidemiology. Annual Review of Phytopathology. 30. 1: 553-577. https://doi.org/10.1146/annurev.py.30.090192.003005
Michailides, T. J. (1991): Pathogenicity, distribution, sources of inoculum, and infection courts of Botryosphaeria dothidea on pistachio. Phytopathology. 81: 566-573. https://doi.org/10.1094/Phyto-81-566

Pavlic, D.-Slippers, B.-Coutinho, T. A.-Gryzenhout, M.-Wingfield, M. J. (2004): Lasiodiplodia gonubiensis sp. nov., a new Botryosphaeria anamorph from native Syzygium cordatum in South Africa. Studies in Mycology. 50. 2:313-322.

Satoko, K.-Takao, K.-Akira, K.-Yshihiro, O. (1999): Conidial Morphology, Pathogenicity and Culture Characteristics of Phomopsis Isolates from Peach. Japanese Pear and Apple in Japan. Annals of the Phytopathological Society of Japan. 65. 3: 264-273. https://doi.org/10.3186/jjphytopath.65.264

Sessa, L.-Abreo, E.-Bettucci, L.-Lupo, S. (2017): Diversity and virulence of Diaporthe species associated with wood disease symptoms in deciduous fruit trees in Uruguay. Phytopathologia Mediterranea. 56. 3: 431-444. https://doi.org/10.14601/Phytopathol_Mediterr-20678

Shay, J. R.-Sitterly, W. R. (1954): Botryosphaeria canker of apple. Phytopathology. 44. 505.

Slippers, B.-Crous, P. W.-Denman, S.-Coutinho, T. A.-Wingfield, B. D.-Wingfield, M. J. (2004): Combined multiple gene genealogies and phenotypic characters differentiate several species previously identified as Botryosphaeria dothidea. Mycologia. 96. 1: 83-101. https://doi.org/10.1080/15572536.2005.11833000

Smit, W. A.-Viljoen, C. D.-Wingfield, B. D.-Wingfield, M. J.Calitz, F. J (1996): A new canker disease of apple, pear, and plum rootstocks caused by Diaporthe ambigua in South Africa. Journal article. Plant Disease. 80. 12: 1331-1335. https://doi.org/10.1094/PD-80-1331

Strange, R. N. P.-Scott, R. (2005): Plant Disease: A Threat to Global Food Security. Annual Review of Phytopathology. 43. 1: 83116. https://doi.org/10.1146/annurev.phyto.43.113004.133839

Sutherland, M. L.-Pearson, S.-Brasier, C. M. (1997): The Influence of Temperature and Light on Defoliation Levels of Elm by Dutch Elm Disease. Phytopathology. 87. 576-581. https://doi.org/10.1094/PHYTO.1997.87.6.576

Sutton, T. B. (1991): White Rot. In: Jones, A. L.-Aldwinckle, H. eds. Compendium of Apple and Pear Diseases. St. Paul, American Phytopathological Society, 16-18.

Tang, W.-Ding, Z.-Zhou, Z. Q.-Wang, Y. Z.-Gou, L. Y. (2011): Phylogenetic and Pathogenic Analyses Show That the Causal Agent of Apple Ring Rot in China Is Botryosphaeria dothidea. Plant Disease. 96. 4: 486-496. https://doi.org/10.1094/PDIS-0811-0635

Thomas, T.-Themis, J. M. (2009): Studies on Diaporthe eres as a New Pathogen of Peach Trees in Greece. Plant Disease. 93. 12: 1293-1297. https://doi.org/10.1094/PDIS-93-12-1293

Úrbez-Torres, J. R.-Boulé, J.-O'Gorman, D. T. (2016): First Report of Diplodia seriata and D. mutila Causing Apple Dieback in British Columbia. Plant Disease. American Phytopathological Society. 100. 6: 1243. https://doi.org/10.1094/PDIS-11-151358-PDN

Valent, B. (1990): Rice blast as a model system for plant pathology. Phytopathology. 80. 1: 33-36. https://doi.org/10.1094/Phyto-8033

van Niekerk, J. M.-Crous, P. W.-Groenewald, J. Z. E.-Fourie, P. H.Halleen, F. (2004): DNA phylogeny, morphology and pathogenicity of Botryosphaeria species on 
DOI: $10.34101 /$ actaagrar/1/3721

grapevines. Mycologia. 96. 4: 781-798.

https://doi.org/10.1080/15572536.2005.11832926

Voglmayr, H.-Castlebury, L. A.-Jaklitsch, W. M. (2017):

Juglanconis gen. nov. on Juglandaceae, and the new family Juglanconidaceae (Diaporthales). Persoonia. 38. 136-155. https://doi.org/10.3767/003158517X694768

White, T. J.-Bruns, T.-Lee, S.-Taylor, J. W. (1990): PCR Protocols: A Guide to Methods and Applications. Academic Press. New York. 482.

Yarwood, C. E. (1983): History of plant pathogen introductions. In: Wilson, CL, Graham CL, Exotic Plant Pests and North American Agriculture. New York, Academic Press, 39-63. 